CATALLAXY

Volume 5 Issue 1 June 2020

e-ISSN 2544-090X

C www.catallaxy.pl

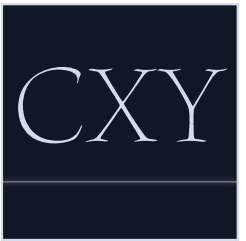

Oryginalny artykut naukowy

otrzymano: 03.04.2020 / zaakceptowano: 13.07.2020 / opublikowano online: 21.07.2020

Ratajczak, J. (2020). Sposoby radzenia sobie ze zmianami demograficznymi w polskich organizacjach. Catallaxy, 5(1): 25-34. doi:10.24136/cxy:2020.003.

\title{
Sposoby radzenia sobie ze zmianami demograficznymi w polskich organizacjach
}

\section{JOANNA RATAJCZAK}

Uniwersytet Ekonomiczny w Poznaniu, Instytut Zarzadzania, Katedra Zarządzania Zasobami Przedsiębiorstwa, al. Niepodlegtości 10, 61-875 Poznań, Polska

曰 joanna.ratajczak@vp.pl

(D) orcid.org/0000-0002-0634-7545

\section{Abstrakt}

Motywacja: Zachodzące obecnie zmiany demograficzne, m.in. zjawisko starzenia się społeczeństwa czy spadek liczby ludności, niewątpliwie stanowią wyzwanie dla współczesnych organizacji. Niezbędne jest wykorzystanie wszystkich dostępnych zasobów ludzkich. Koniecznością staje się zatem zmiana polityki personalnej wielu przedsiębiorstw. Cel: Celem artykutu jest rozpoznanie sposobów radzenia sobie pracodawców ze zmianami demograficznymi zachodzącymi na rynku pracy.

Materiały i metody: Wykorzystano następujące metody badawcze: studium przypadku, sondaż diagnostyczny (ankieta i wywiad), analiza dokumentów. Dane pozyskano z kilkunastu polskich organizacji.

Wyniki: Zaprezentowano praktyki z zakresu polityki personalnej w obszarze rekrutacji, motywowania, rozwoju i oceny pracowników stosowane w analizowanych przedsiębiorstwach, których celem jest jak najlepsze zarządzanie pracownikami zróżnicowanymi wiekowo. W konsekwencji może być to odpowiedzią na zmiany demograficzne występujące na rynku pracy, m.in. niedobór pracowników i różnice międzypokoleniowe. Niewątpliwie dobrym rozwiązaniem istniejącej na rynku pracy sytuacji może być tzw. zarządzanie wiekiem, czyli wprowadzenie odpowiednich metod zarządzania zróżnicowanym wiekowo zespotem, który odpowiada wszystkim pracownikom, niezależnie od tego, do której grupy pokoleniowej należą. Zgodnie z uzyskanymi wynikami, w niewielu przedsiębiorstwach wykorzystuje się tego typu praktyki. Często jest to rezultatem typu kultury organizacyjnej lub generalnie braku istnienia w organizacji zaawansowanych systemów personalnych. Mimo, że pracodawcy dostrzegają szereg problemów związanych z pracą zespołów wielopokoleniowych, rzadko stosują rozwiązania systemowe, które mogłyby ułatwić wspótpracę międzypokoleniową w przedsiębiorstwie oraz odpowiedzieć na potrzeby różnych generacji pracowników.

Stowa kluczowe: zmiany demograficzne; starzenie się spoleczeństwa; pokolenie; zarzadzanie wiekiem JEL:J11;J53; M51

1. Wprowadzenie

Zauważalne obecnie zmiany demograficzne na rynku pracy, m.in. starzenie się społeczeństwa, spadek liczby urodzeń, zwiększenie przeciętnej długości życia obywateli czy wcze- sna dezaktywizacja zawodowa, tak w Polsce, jak i w całej Europie, stanowią wyzwanie zarówno dla pracodawców, jak i pracowników. Powodują one konieczność przemian polityki personalnej większości przedsiębiorstw, co prowadzić będzie do wykorzystania poten- 
cjału wszystkich zatrudnionych. Jednym z rozwiązań tej sytuacji może być właściwe zarządzanie pracownikami zróżnicowanymi wiekowo w organizacji.

Celem artykułu jest rozpoznanie sposobów radzenia sobie pracodawców ze zmianami demograficznymi zachodzącymi na rynku pracy.

W sekcji 2. omówiono zachodzące obecnie przemiany demograficzne i ich skutki dla rynku pracy. Zaprezentowano również praktyki zarządzania międzypokoleniowego, które są odpowiedzią na zaistniałą sytuację. Warto zaznaczyć, że są one determinowane przez wiele czynników, a kluczowym z nich wydaje się być typ kultury organizacyjnej. Podjęto zatem próbę ustalenia, który $z$ nich $w$ największym stopniu sprzyja skutecznemu zarządzaniu zespołami zróżnicowanymi wiekowo. W sekcji 3. opisano wykorzystane materiały i metody. W sekcji 4. przedstawiono otrzymane wyniki, natomiast $\mathrm{w}$ sekcji 5. zawarto podsumowanie przeprowadzonej analizy.

\section{Przegląd literatury}

\subsection{Obecne zmiany demograficzne na rynku pracy}

Właściwe we wszystkich państwach europejskich, również w Polsce od kilku lat widoczne staje się zjawisko starzenia się społeczeństwa, definiowane jako „systematyczny wzrost odsetka osób starszych w populacji” (Klimczuk 2012, s. 244). Przyczynami takiego stanu rzeczy są przede wszystkim: wzrost długości życia jednostki (wynikający głównie ze zmian technologicznych, wzrostu gospodarczego, lepszych warunków życia i rozwoju medycyny), niski poziom dzietności oraz ujemny wskaźnik bilansu migracji (Schimanek i in., 2015, s. 10). Prognozuje się systematyczny spadek liczby ludności do 32,1 mln w 2050 roku, z czego 30,2\% stanowić będą obywatele po 65. roku życia (Waligórska i in., 2014, s. 155, 166). Skutkiem będzie zatem wzrost wskaźnika obciążenia demograficznego. Widoczny jest stały spadek siły roboczej, jak również zjawisko wczesnej dezaktywizacji zawodowej (Fura i Fura, 2012, s. 306). W rezultacie wydłużenie się okresu aktywności zawodowej staje się koniecznością (Szaban, 2013, s. 149).

$\mathrm{Na}$ rynku pracy znajdują się obecnie aż cztery pokolenia: baby boomers, X, Y i Z, które prezentują odmienne podejście do życia i pracy. Mimo to muszą ze sobą konstruktywnie współpracować. O przynależności do danej generacji decyduje $\mathrm{w}$ głównej mierze światopogląd jednostki, jednak można przyjąć ogólne ramy pokoleniowe, które wyznacza data urodzenia. Do pokolenia baby boomers przypisuje się zazwyczaj osoby urodzone w latach 1945-1965, do pokolenia X urodzonych między 1965 a 1980 rokiem, pokolenie Y stanowią osoby urodzone w latach 1980-1995, a generacja $Z$ to urodzeni po 1995 roku. Jest to oczywiście spore uproszczenie, a data urodzenia nie powinna być jedynym wyznacznikiem przynależności do danego pokolenia.

Jednocześnie pracodawcy niechętnie zatrudniają osoby młode nieposiadające dużego doświadczenia zawodowego oraz osoby starsze mogące $w$ najbliższych latach osiągnąć wiek emerytalny. Muszą jednak pogodzić się z sytuacją, w której maleje liczba pracowników najchętniej zatrudnianych, tj. w wieku 30-45 lat. Konieczna jest więc zmiana nastawienia. Warto wspomnieć, że według badań, celowe tworzenie różnorodnych zespołów pracowniczych (pod względem wieku, ale też płci, pochodzenia kulturowego, itp.) niesie za sobą wiele korzyści. Stanowi to potencjał, który można wykorzystać (Skowron-Mielnik, 2013, s. 63). Przedsiębiorstwo może nabyć odmienne doświadczenia, kompetencje i predyspozycje swoich pracowników, co pozwala na lepsze dopasowanie się do wymagań zmiennego rynku i wymagań klientów (Liwiński i Sztanderska, 2010). Zespoły pracownicze, zróżnicowane wiekowo pozwalają też na międzypokoleniowe przekazywanie wiedzy i doświadczenia, przyczyniając się tym samym się do zachowania ciągłości zasobów wiedzy i umiejętności w organizacji (Pawlak, 2016, s. 413). 


\subsection{Zarządzanie międzypokoleniowe}

Dobrym rozwiązaniem, wspierającym pracę zespołu pracowników zróżnicowanych wiekowo, jest zarządzanie międzypokoleniowe, czyli taki poziom zarządzania wiekiem, w którym działania kierowane są do wszystkich grup pokoleniowych, zatrudnionych $\mathrm{w}$ organizacji. Pozwala na optymalne wykorzystanie dostępnego kapitału ludzkiego, co, jak wydaje się, jest najlepszym możliwym rozwiązaniem obecnej sytuacji demograficznej. Poziomy zarządzania zespołami zróżnicowanymi wiekowo $\mathrm{w}$ przedsiębiorstwie zaprezentowano na schemacie 1. Najniższy $z$ nich odpowiada sytuacji, w której w przedsiębiorstwie nie mają miejsca żadne działania $z$ tego obszaru. Kolejne dwa dotyczą zarządzania wiekiem, które skierowane jest do wybranej grupy pracowników. Zarządzanie wiekiem często rozumiane jest właśnie jako działania skierowane jedynie do najstarszych zatrudnionych i mające na celu ich aktywizację. To oczywiście ważna kwestia, o tyle istotna, że współczesne organizacje muszą poradzić sobie $z$ wyzwaniami demograficznymi. Warto jednak odpowiadać na potrzeby wszystkich pokoleń pracowników zatrudnionych $w$ organizacji. Tylko wtedy działania organizacji $\mathrm{w}$ tym obszarze będą $w$ pełni efektywne. Tak skonstruowane zarzadzanie wiekiem nazwać można zarządzaniem międzypokoleniowym (Woszczyk i Warwas, 2016, s. 44). Z pewnością jest ono skuteczniejsze $\mathrm{w}$ procesie motywowania pracowników i zwiększania wydajności ich pracy. Co więcej, będąc nastawionym na wszystkich pracowników, w zależności od ich wieku, działa prewencyjnie, $w$ przeciwieństwie do zarządzania wiekiem skupiającego się na naprawczych działaniach, skierowanych jedynie do najstarszych pracowników. Zarządzanie międzypokoleniowe jest zatem najbardziej zaawansowanym poziomem zarządzania wiekiem w organizacji. Wynika z dojrzałości polityki personalnej przedsiębiorstwa.

\section{Materiały i metody}

Działania z obszaru zarządzania międzypokoleniowego są determinowane m.in. przez typ kultury organizacyjnej. Watro poddać analizie, który z nich, zgodnie z typologią Camerona i Quinna (2015), w największym stopniu ułatwia organizację działań $z$ zakresu zarządzania międzypokoleniowego i jest $\mathrm{w}$ związku z tym najkorzystniejszy dla pracowników przedsiębiorstwa.

Cameron i Quinn (2015, ss. 45-53) rozróżnili cztery typy kultury organizacyjnej: kulturę hierarchii, klanu, adhokracji i rynku. Organizacje, w których ma miejsce kultura hierarchii są zazwyczaj silnie ustrukturyzowane i dobrze koordynowane. Stabilność i ciągła kontrola, jak również orientacja na sprawy wewnętrzne są widoczne na każdym etapie zarządzania. Organizację o kulturze klanu porównać można do rodziny. Zauważalne jest tu elastyczność i swoboda działania, a także orientacja na sprawy wewnętrzne, na ludzi i procesy. Przywódca określany jest jako mentor, doradca i ojciec. Kulturę adhokracji charakteryzuje elastyczność, swoboda działania, orientacja na pozycję w otoczeniu i zróżnicowanie. Jest więc zorientowana zewnętrznie, elastyczna, innowacyjna, dynamiczna i przedsiębiorcza. Z kolei kulturę rynku cechuje stabilność, kontrola i orientacja na pozycję w otoczeniu Wśród kryteriów efektywności wymienić można: udział w rynku, osiąganie celów i pokonywanie konkurencji. Ważna jest zatem skuteczna realizacja zadań, zorientowanie na wyniki i reputacja organizacji. Pracownicy ambitnie podchodzą do swojej pracy, a sukcesy są wspólnie celebrowane (Schein, 2010, s. 168).

Można przypuszczać, że będzie to kultura klanu, gdyż wpisane są $\mathrm{w}$ nią szacunek dla pracowników, ceniona jest integracja zespołu i umiejętność współpracy, a pracodawca stara się zaspokoić potrzeby wszystkich pracowników (Schein, 2010, s. 168), co wpisuje się też w założenia zarządzania międzypokoleniowego. Natomiast pozostałe typy kultury organizacyjnej nie będą sprzyjać istnieniu $w$ organizacji praktyk $z$ zakresu zarządzania 
międzypokoleniowego. Wydaje się, że szczególnie będzie to utrudnione $\mathrm{w}$ organizacji o kulturze rynku, gdzie ważniejsze od polityki personalnej są zwykle wyniki (głównie finansowe). $Z$ kolei $w$ przedsiębiorstwach o kulturze typu hierarchia, praktyki te będą skierowane jedynie do najstarszych zatrudnionych, co ma na celu ochronę przed utratą wiedzy po przejściu starszych pracowników na emeryturę. Natomiast w przypadku kultur adhokracyjnych, widoczne jest nastawienie na rozwój nowoczesnych technologii i innowacyjność rozwiązań niż na zaawansowany rozwój polityki personalnej.

Analiza składała się $z$ dwóch etapów. $\mathrm{W}$ pierwszym przeprowadzono badania ankietowe $\mathrm{w}$ formie elektronicznej. Kwestionariusz ankiety umieszczono $\mathrm{w}$ kilku serwisach przeznaczonych do przeprowadzenia badań, tj. Survio (2020), Ankieter (2020). Link do kwestionariusza umieszczonego $\mathrm{w}$ formularzu Google rozesłano do ponad trzystu organizacji, jednak w tej części badania wzięło udział czterdziestu anonimowych pracowników przedsiębiorstw działających na terenie Polski. Pytania ankietowe dotyczyły istniejących $w$ przedsiębiorstwie przejawów kultury organizacyjnej, zgodnie $z$ kwestionariuszem badania kultury organizacyjnej Camerona i Quinna (2015) oraz zarządzania pracownikami zróżnicowanymi wiekowo.

W drugim etapie zastosowano metodę studium przypadku, gdzie skupiono się na rozpoznaniu praktyk zarządzania międzypokoleniowego $\mathrm{w}$ dwóch organizacjach Inei Sp. z o.o. i Aquanet Sp. z o.o., w których przeprowadzono ankietę wśród szeregowych pracowników, wywiady ustrukturyzowane z menedżerami różnych działów i szczebli, analizę dokumentów oraz obserwację pracy w działach wielopokoleniowych. Pierwsza ze wspomnianych organizacji to operator telewizji kablowej, który oferuje swoim klientom również dostęp do internetu, telefonii stacjonarnej i komórkowej. Działa na terenie województwa wielkopolskiego. Natomiast Aquanet jest przedsiębiorstwem wodno-kanalizacyjnym, działającym na terenie Poznania.

\section{Wyniki badania}

Na podstawie pierwszego etapu analizy można wyciągnąć wniosek, że jedynie w dwóch organizacjach miały miejsce zróżnicowane działania z zakresu polityki personalnej, skierowane do różnych grup wiekowych pracowników. Stanowiły one oddzielny system zarządzania międzypokoleniowego $\mathrm{w}$ przedsiębiorstwie. Co ciekawe, w tych organizacjach występowała kultura organizacyjna typu rynek i adhokracja. Pierwsza $z$ nich jest przedsiębiorstwem o przewadze kapitału niemieckiego, działającym w branży zasobów ludzkich (human resources, HR). Druga to polskie, prywatne przedsiębiorstwo $z$ branży produktów szybkopozbywalnych (fast-moving consumer goods, FMCG).

Zgodnie $z$ literaturą przedmiotu, zarządzanie wiekiem najczéściej dotyczy jedynie najstarszych osób, zatrudnionych w przedsiębiorstwie (Ratajczak, 2018, s. 320). Ma na celu ułatwić proces ich odejścia z organizacji. Obejmuje m.in.: wsparcie psychologiczne, programy medyczne, dopasowane do potrzeb osób po 60. roku życia, możliwość stopniowego obniżania wymiaru etatu lub pracy zdalnej oraz programy mentoringu umożliwiające przekazanie wiedzy młodszym pracownikom.

$\mathrm{Na}$ podstawie drugiego etapu badań przeprowadzonych w Aquanet i Inei, można wyciągnąć wniosek, że $w$ pierwszym $z$ tych przedsiębiorstwa występowała kultura hierarchii, choć w codziennych, oddolnych kontaktach międzyludzkich widoczne były również przejawy kultury klanu. $Z$ kolei w Inei miały miejsce praktyki i wartości charakterystyczne zarówno dla kultury rynku, jak i adhokracji, co było rezultatem specyfiki działalności tej organizacji, opierającej się na dwóch filarach sprzedażowym i technologicznym. Zarówno w Aquanet, jak i w Inei nie występował osobny system zarządzania wiekiem (nie wspominając o zarządzaniu międzypokoleniowym). W obu organizacjach istniały jednak pojedyncze elementy, które należały do innych systemów kadrowych, które można uznać za elementy zarządzania zróżnicowanymi pod względem wieku pracownikami. 
4.1. Praktyki z zakresu rekrutacji jako odpowiedź na sytuację demograficzną na rynku pracy

Zgodnie $z$ wynikami uzyskanymi w pierwszym etapie badania, $w$ obu organizacjach, w których działał odrębny system zarządzania wiekiem, był on skierowany zarówno do najstarszych pracowników, jak i tych nowozatrudnionych. Ogłoszenia o pracę były w nich tworzone $z$ myślą o konkretnej grupie wiekowej odbiorców. Zwracano uwage przede wszystkim na język oraz miejsce umieszczenia ogłoszenia. Co więcej, organizacja typu adhokracja dążyła do odmłodzenia swojej kadry przez: tworzenie klas patronackich, udział $\mathrm{w}$ targach pracy na uczelniach i organizacje programów stażowych dla studentów. W ten sposób pozyskiwano młodych pracowników. Natomiast w kulturze organizacyjnej typu rynek nowoprzyjęte osoby wprowadzane były przez zespół leadera. Przez pierwsze miesiące znajdowały się też w tzw. „okresie ochronnym”, podczas którego nie podlegały ocenie i nie można było ich zwolnić.

W obu organizacjach, uczestniczących w drugim etapie badania, wyróżnić można było również działania $\mathrm{w}$ obszarze rekrutacji dostosowane do oczekiwań różnych pokoleń. Warto zauważyć, że Aquanet objął patronatem klasę, w której uczniowie uczyli się zawodu instalator sieci i urządzeń sanitarnych w Zespole Szkół Budowlanych w Poznaniu. Dzięki temu przedsiębiorstwo uczestniczyło w edukacji przyszłych pracowników. W ten sposób starano się zachęcić młodzież do podjęcia pracy w Aquanet. Inne działania z zakresu zarządzania wiekiem $\mathrm{w}$ zakresie rekrutacji pracowników były jednak niezauważalne.

W Inei również stosowano różne kanały dotarcia do potencjalnych pracowników należących do różnych pokoleń. Co istotne, jak wspomniano, w organizacji tej odnotowano przejawy dwóch kultur organizacyjnych. Kultura typu rynek występowała przede wszystkim $\mathrm{w}$ dziale sprzedażowym zakładającym bezpośrednią obsługę klientów. Z kolei przejawy kultury o typie adhokracji miały miejsce przede wszystkim $\mathrm{w}$ dziale informatycznym (information technology, IT). Podejście do zarządzania pracownikami w odmiennym wieku było więc inne $\mathrm{w}$ obu tych działach. W procesie rekrutacji do działu sprzedażowego stosowano odmienny sposób komunikacji z kandydatami starszymi i młodszymi. $Z$ kolei $w$ dziale IT postulowano zastosowanie tych samych źródeł pozyskania kandydatów i sposób komunikacji, niezależnie od ich grupy wiekowej, co wynikało ze specyfiki pracy na stanowiskach informatycznych. Co ciekawe, zarząd organizacji również nie zalecał różnicowania źródeł rekrutacji, jak również innych rozbieżności, nawet jeśli miałyby być one obecne jedynie $\mathrm{w}$ języku zastosowanym w ogłoszeniu lub podczas rozmowy kwalifikacyjnej.

\subsection{Praktyki z zakresu motywowania pracowników}

W organizacji typu adhokracja, w której występuje odrębny system zarządzania wiekiem, pracownikom proponuje się odmienne benefity, w zależności od grupy pokoleniowej, do której nalezą. Natomiast w przedsiębiorstwie charakteryzującym się kulturą typu rynek, jednym $z$ kryteriów awansu jest wiek pracownika. Leaderem zespołu mogą zostać jedynie najstarsi zatrudnieni. Osoba na takim stanowisku może liczyć na szereg korzyści. Otrzymuje prowizję i dodatkowe benefity za wynik zespołu, którym kieruje.

W Aquanet nie występują zróżnicowane bonusy ze względu na wiek pracowników. Ankietowani menedżerowie podkreślali jednak, że dobrym pomysłem byłoby wprowadzenie korzyści skierowanych do określonych grup odbiorców w różnym wieku, np. sfinansowanie żłobka i przedszkola dla dzieci pracowników pokoleń Y i Z, szkolenia eksperckie dla pracowników pokolenia $X$, a także szersze działania skierowane do pracowników pokolenia wyżu demograficznego. Ich zdaniem konieczne byłoby przywrócenie dodatku na szkolenia, który w przedsiębiorstwie został zniesiony kilka lat temu.

Również w Inei wszystkie benefity kierowane były do pracowników bez względu na ich przynależność do danej grupy pokoleniowej. Co więcej, żaden $z$ ankietowanych pracowni- 
ków nie zadeklarował, że był niezadowolony $z$ takiego rozwiązania. Wszyscy respondenci uznali za niewłaściwe różnicowanie korzyści, niosące za sobą ryzyko dyskryminacji niektórych grup osób zatrudnionych. Jedynym dopuszczalnym rozwiązaniem byłoby wprowadzenie systemu kafeteryjnego, z którego każdy pracownik mógłby wybrać elementy motywacyjne, które go interesują.

\subsection{Praktyki z zakresu rozwoju pracowników}

Zgodnie $z$ wynikami uzyskanymi w pierwszym etapie badania, $w$ dwóch organizacjach $z$ kulturą typu rynek i adhokracja, w których miał miejsce odrębny system zarządzania wiekiem, promowano kształcenie ustawiczne przez dofinansowanie studiów podyplomowych i szkoleń. Jednocześnie warto zauważyć, $\dot{z}$ e odmienne szkolenia były proponowane różnym grupom wiekowym osób zatrudnionych. Warto też wspomnieć, że występował w nich system intermentoringu, $w$ którym pary pracowników są dla siebie równocześnie mentorami i mentee.

W Aquanet istniały działania, które uznać można za mentoring. W wielu działach nowy pracownik otrzymywał opiekuna, czyli doświadczoną osobę, która pracuje w organizacji od wielu lat. Miał ona za zadanie wprowadzić go $\mathrm{w}$ pracę. Opiekun otrzymywał nagrodę pieniężną w zamian za swoje dodatkowe obowiązki, której poziom zależał jednak od uznania bezpośredniego przełożonego. Należy tu podkreślić, że w organizacji nie było formalnego systemu mentoringu. Przypisanie opiekuna było indywidualną decyzją kierownika zespołu. Aquanet promował również uczenie się przez całe życie, organizując lekcje języka angielskiego w czasie pracy i współfinansując studia podyplomowe, pod warunkiem, że ich kierunek był zgodny z potrzebami przedsiębiorstwa.

W Inei również występował mentoring, lecz był on sformalizowany. Udział w nim był obowiązkowy dla wszystkich nowozatrudnionych pracowników, jednak jego przebieg zależal od działu. W dziale sprzedażowym osoba wytypowana przez przełożonego do objęcia funkcji mentora, mogła odmówić, jednak podkreślano, że jak dotąd nigdy nie miało to miejsca, a mentor otrzymuje za swoje działania dodatkową gratyfikację pieniężną. $Z$ kolei $w$ dziale informatycznym, mentorzy zmieniali się co tydzień tak, aby mentorowany miał możliwość uczyć się od różnych osób pracujących w dziale. Co ciekawe, zarząd nie miał dobrego zdania na temat samego procesu mentoringu. Miał obiekcje co do jego skuteczności. Wskazywano, że jego skuteczność zależy w dużej mierze od osoby mentora, z czym zresztą trudno się nie zgodzić.

Szkolenia kierowane do pracowników Inei również nie były zróżnicowane ze względu na wiek, jednak na ten temat zdania także były podzielone. W dziale IT wskazywano na konieczność organizacji szkoleń z zakresu kompetencji miękkich, skierowanych do pracowników z pokoleń $Y$ i Z. Natomiast ankietowany członek zarządu, zauważył $z$ kolei konieczność zróżnicowania metod przeprowadzania szkoleń w taki sposób, aby tempo nauki dostosowane było do grupy odbiorczej. $Z$ kolei do pracowników najmłodszych powinny być kierowane szkolenia $\mathrm{w}$ formie online. Warto zaznaczyć, że odmiennego zdania byli respondenci $z$ działów personalnego i sprzedaży, którzy sprzeciwiali się różnicowaniu tematyki i formy szkoleń.

\subsection{Praktyki z zakresu oceny pracowniczej}

W Aquanet oraz w Inei nie występowały żadne praktyki z zakresu oceny pracowniczej, które można byłoby zaliczyć do zarządzania wiekiem, a tym bardziej do zarządzania międzypokoleniowego.

$Z$ kolei $w$ jednej $z$ pozostałych analizowanych organizacji szczegółowa ocena pracownicza ( $w$ formie oceny $360^{\circ}$ ) odbywała się raz $\mathrm{w}$ roku, jednak pracownicy mieli możliwość uzyskania częstszej informacji zwrotnej od bezpośredniego przełożonego (nawet raz w miesiącu), jeśli zgłaszali taką potrzebę. Zauważalne było, że $z$ tej możliwości korzystali głównie pracownicy $z$ pokoleń $Y$ i $Z$, co potwierdza istnienie zapotrzebowania na częstszą odpowiedź wśród najmłodszych grup 
wiekowych. Wydaje się więc, że jest to dobra praktyka, która może być zarekomendowana również innym przedsiębiorstwom.

Natomiast w organizacji o kulturze typu rynek, której pracownik wziął udział w pierwszym etapie badania, występowały odmienne kryteria oceny dla osób młodszych i starszych, mimo że zajmowały one te same stanowiska, co nie było dobrze przyjmowane przez pracowników.

\subsection{Inne praktyki zarządzania wiekiem i międzypokoleniowego}

W Aquanet występowały również szeroko zakrojone działania $\mathrm{w}$ dziedzinie ochrony zdrowia, które z pewnością zaliczyć można do zarządzania wiekiem, m.in.: współfinansowanie prywatnej opieki medycznej, kampanie krwiodawstwa, mammografia dla kobiet, badanie znamion i organizacja tzw. dni zdrowia. Warto podkreślić, że starsi pracownicy należący do pokolenia baby boomers mogli liczyć na szerszy pakiet badań medycznych i częściej niż jest to wymagane przez prawo, uczestniczyli w badaniach okresowych.

Dla pracowników w wieku przedemerytalnym zorganizowano również spotkania informacyjne we współpracy $z$ Zakładem Ubezpieczeń Społecznych. Należy podkreślić, że chociaż nie była to praktyka odgórna, niektórzy menedżerowie zlecali mniej męczące zadania pracownikom pokolenia wyżu demograficznego. Było to szczególnie ważne w przypadku pracowników fizycznych, których stan zdrowia nie pozwal na dalsze wykonywanie bieżących obowiązków.

Pracownicy na stanowiskach biurowych mieli również możliwość skorzystania z elastycznego czasu pracy (przyjazd do pracy dozwolony był od godziny 7:00 do 10:00) oraz do pracy $z$ dalnej $w$ ciągu jednego dnia co dwa tygodnie, co z pewnością ułatwiało pogodzenie pracy i życia osobistego, które jest szczególnie ważne dla młodszych pokoleń.

W organizacji co roku tworzone były również plany zatrudnienia (uwzględniające przejścia na emeryturę i zapotrzebowanie na nowych pracowników). Niestety nie były one związane $z$ planami sukcesji pracowników, chociaż zarówno menedżerowie, jak i stali pracownicy uważali, że było to niezbędne. Warto podkreślić, że niektórzy menedżerowie zespołów wielopokoleniowych, $\mathrm{w}$ ramach wspomnianego wcześniej nieformalnego monitoringu, wybierali pary pracowników, którzy będą dzielić się swoją wiedzą i doświadczeniem. W parze takiej znajdował się zawsze pracownik, który $\mathrm{w}$ najblizsszych latach miał przejść na emeryturę oraz pracownik nowozatrudniony.

W organizacji wspierano także współpracę międzypokoleniową przez organizację pikniku firmowego, który umożliwiał integrację pracowników w różnym wieku oraz organizację szkoleń młodych pracowników, które były prowadzone przez doświadczonych pracowników. Warto zauważyć, ze pracownicy brali udział $\mathrm{w}$ szkoleniach mających na celu zapobieganie dyskryminacji ze względu na wiek, jednak zauważalne było jednocześnie, że w Aquanet nie podejmowano żadnych działań, które mogłyby zapobiec konfliktom międzypokoleniowym.

Również w Inei oferowano szereg aktywności osobom $\mathrm{w}$ wieku przedemerytalnym. Mogli oni, podobnie jak inni pracownicy, skorzystać z systemu pracy zdalnej i programów rehabilitacji. Równocześnie zorganizowano również warsztaty, które miały pokazać młodszym pracownikom, jak funkcjonują osoby starsze.

Wśród pakietów prywatnej opieki medycznej znajdowały się z kolei takie, które dedykowane były różnym grupom wiekowym. Każdy pracownik mógł wybrać taki pakiet, który najbardziej odpowiadał jego potrzebom.

Osobom zatrudnionym oferowano również wiele innych działań z obszaru promocji zdrowia, np. program szczepień, kartę sportową, fit club. Na terenie przedsiębiorstwa znajdowała się rowerownia i prysznice, co miało na celu zachęcenie pracowników do przyjeżdżania do pracy rowerem, a równocześnie wpisywało się $\mathrm{w}$ działania proekologiczne.

$\mathrm{W}$ organizacji nie istniały plany sukcesji pracowniczej, natomiast praktyki zarządzania odejściami były częścią zarządzania talentami. 
Każdy pracownik ustalał wraz z przełożonym indywidualną ścieżkę kariery. Jeśli chciał zakończyć współpracę $z$ przedsiębiorstwem, przeprowadzano $z$ nim rozmowę, tzw. exit interview.

Większość respondentów zgodnie uznała, że w organizacji nie miały miejsca działania $z$ zakresu zapobiegania dyskryminacji ze względu na wiek. Podkreślono również, że nie było takiej potrzeby, gdyż ageizm nie występował w Inei. Ankietowany członek zarządu zaznaczył, że w Inei istniał kodeks etyki oraz procedury mające na celu zapobieganie dyskryminacji (każdej, nie tylko tej ze względu na wiek). Zastanawia zatem, dlaczego inni respondenci o tym nie wspomnieli. Być może, $z$ uwagi na brak przejawów dyskryminacji, były to nieużywane procedury, o istnieniu których niektórzy pracownicy nawet nie wiedzieli.

Jednocześnie w Inei w żaden sposób nie wspierano współpracy międzypokoleniowej, mimo że zatrudniony był $\mathrm{w}$ niej wielopokoleniowy zespół pracowników. Jedynie pracownik działu HR zwrócił uwagę na fakt, że $\mathrm{w}$ przedsiębiorstwie odbyły się warsztaty na temat radzenia sobie $z$ trudnymi sytuacjami w zespole, które można zaliczyć do działań wspierających pracę osób $\mathrm{w}$ różnym wieku. Pozostali respondenci nie uznali jednak, że to działanie miało taki efekt. Podkreślali natomiast, że w Inei wiek nie stanowił kryterium różnicowania personelu. Ankietowany członek zarządu zauważył, że poziom współpracy międzypokoleniowej w organizacji nie był idealny, a jedynie satysfakcjonujący. Być może zatem należałoby zastanowić się nad szerszym wsparciem współpracy pracowników należących do odmiennych pokoleń.

\section{Zakończenie}

Zarządzanie międzypokoleniowe może stanowić jedno ze skuteczniejszych rozwiązań, które skutkować będzie przyciągnięciem do organizacji wartościowych pracowników należących do różnych pokoleń, co jest niezbędne $\mathrm{w}$ obecnej, trudnej sytuacji demograficznej mającej miejsce na rynku pracy.
Warto podkreślić, że zdecydowana większość respondentów (85,7\%) opowiadała się za wprowadzaniem $\mathrm{w}$ przedsiębiorstwie elementów zarządzania międzypokoleniowego, z czego 11,0\% uważało, że elementy te powinny stanowić oddzielną politykę personalną. Jedynie pracownicy działu personalnego i sprzedażowego Inei byli przeciw takiemu rozwiązaniu. Inne zdanie na ten temat miał natomiast ankietowany członek zarządu Inei, który uważał, że pojedyncze praktyki zarządzania międzypokoleniowego mogą przynieść organizacji szereg korzyści. Również pracownik działu informatycznego, który uważał, że dobrym pomysłem byłoby nie tylko wprowadzenie pojedynczych praktyk $z$ tego obszaru, ale też, że powinny one stanowić spójny system zarządzania międzypokoleniowego. Co więcej, jego zdaniem Inei od kilku lat zmierza już w tym kierunku. Świadczy to o tym, że praktyki $z$ tego zakresu mają sens. Oczywiście, nie powinny być one przesłanką do dyskryminacji żadnej grupy pracowników. W niniejszym artykule wskazano szereg rozwiązań, które nie niosą za sobą takiego niebezpieczeństwa.

Podsumowując, na podstawie przeprowadzonej analizy można wskazać, że najmniej korzystna dla zarządzania międzypokoleniowego była kultura organizacyjna typu hierarchia, gdyż jedynie $w$ przedsiębiorstwach hierarchicznych nie występowały (lub były bardzo niwelowane przez obowiązujące i narzucone odgórnie procedury, jak w Aquanet) praktyki zarządzania wiekiem na jego najwyższym poziomie. Nie znaleziono natomiast potwierdzenia dla przypuszczenia, że najkorzystniejszym dla zarządzania międzypokoleniowego typem kultury organizacyjnej jest klan. Należy w tym miejscu podkreślić, że próba badawcza była zbyt mała, aby można było generalizować wyniki.

\section{Bibliografia}

Ankieter. (2020). Pobrane 10.07.2020 z https://ankieter.pl.

Cameron, K.S., i Quinn, R.E. (2015). Kultura organizacyjna: diagnoza i zmiana: model wartości konkurujacych. Warszawa: Wolter Kluwer. 
Fura, M., i Fura, B. (2012). Zasoby pracy w Polsce i Unii Europejskiej w świetle kryzysu demograficznego. Nierówności społeczne a wzrost gospodarczy, 24.

Klimczuk, A. (2012). Społeczeństwo wielokulturowe i srebrna gospodarka: wielokulturowość w kontekście starzenia się ludności. W: M. Biernacka, K. Krzysztofek, i A. Sadowski (red.), Społeczeństwo wielokulturowe: nowe wyzwania i zagrożenia. Białystok: Uniwersytet w Białymstoku.

Liwiński, J., i Sztanderska, U. (2010). Zarządzanie wiekiem $w$ przedsiębiorstwie. Warszawa: Uniwersytet Warszawski.

Pawlak, J. (2016). Zarządzanie wiekiem jako sposób przeciwdziałania nierównościom społeczno-ekonomicznym oraz konfliktom międzypokoleniowym w przedsiębiorstwie. Nierówności Spoteczne a Wzrost Gospodarczy, 46(2).

Ratajczak, J. (2018). Zarządzanie międzypokoleniowe $\mathrm{w}$ wielkopolskich organizacjach $\mathrm{W}$ : B. Borusiak (red.), Gospodarka, technologia, społeczeństwo. Poznań: Bogucki Wydawnictwa Naukowe.

Schein, E.H. (2010). Organizational culture and leadership. San Francisco: Joessey-Bass.

Schimanek, T., Kotzlan, J., i Arczewska, M. (2015). Zarzadzanie wiekiem skierowane na osoby 50+: poradnik dla matych i średnich przedsiębiorców $i$ nie tylko. Pobrane 07.07.2020 z http://odpowiedzialnybiznes.pl.
Skowron-Mielnik, B. (2013). Zarządzanie zasobami ludzkimi w kontekście wyzwań demograficznych. Prace Naukowe Uniwersytetu Ekonomicznego we Wroctawiu, 277.

Survio. (2020). Pobrane 10.07.2020 z https://www. survio.com.

Szaban, J.M. (2013). Praktyki i dobre praktyki zarządzania wiekiem w małych i średnich przedsiębiorstwach. Zarządzanie Zasobami Ludzkimi, 3-4.

Waligórska, M., Kostrzewa, Z., Potyra, M., i Rutkowska, L. (2014). Prognoza ludności na lata 2014-2050. Pobrane 07.07.2020 z https://stat. gov.pl.

Woszczyk, P., i Warwas, I. (2016). Od zarządzania wiekiem do zarządzania międzypokoleniowego: ujęcie strategiczne. W: J. Wiktorowicz, I. Wyrwas, M. Kuba, E. Staszewska, P. Woszczyk, A. Stankiewicz, i J. Kliombka-Jarzyna (red.), Pokolenia: co się zmienia: kompendium zarzadzania multigeneracyjnego. Warszawa: Wolter Kluwer.

\section{Informacje uzupełniające}

Wkład autorski: autor zaakceptował ostateczną wersję artykułu.

Źródła finansowania: artykuł został w całości sfinansowany ze środków własnych autora. 
Aneks

Schemat 1.

Poziomy zarządzania wiekiem $w$ organizacji

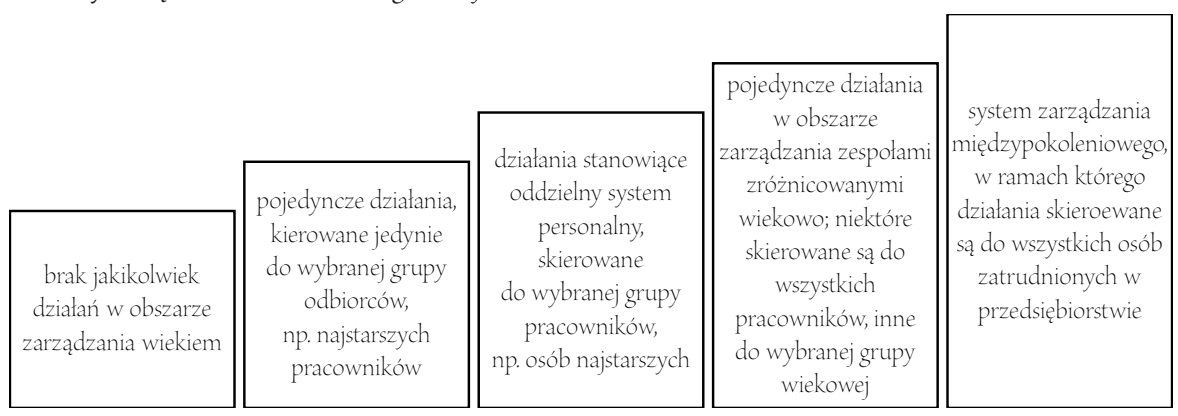

Źródło: Opracowanie własne.

Ways to deal with demographic changes in Polish organizations

\begin{abstract}
Motivation: Demographic changes currently under way, such as the phenomenon of the aging of the population or the decline in the population, undoubtedly pose a challenge to modern organizations. It is necessary to use all available human resources. Therefore, it is necessary to change the personnel policy of many enterprises.

Aim: The aim of the article is to identify ways in which employers cope with demographic changes taking place on the labor market.

Materials and methods: The following research methods were used: case study, survey, interview and document analysis. Data were obtained from several Polish organizations.

Results: Practices in the field of personnel policy in the area of recruitment, motivation, development and evaluation of employees, used in the surveyed enterprises, whose goal is the best management of age-diverse employees were presented. As a result, this may be a response to demographic changes in the labor market, such as shortage of employees and intergenerational differences. Undoubtedly, a good solution to the existing situation on the labor market may be the so-called age management, i.e. the introduction of appropriate methods for managing an age-diverse team that suits all employees, regardless of which generation group they belong to. According to the results obtained, few companies use this type of practice. Often this is due to the type of organizational culture or generally due to the lack of existence of advanced personnel systems in the organization. Although employers see a number of problems related to multi-generational teams, they rarely use system solutions that could facilitate intergenerational collaboration in an enterprise and respond to the needs of different generations of employees.
\end{abstract}

Keywords: demographic changes; aging population; generation; age management JEL: J11;J53; M51 